\title{
Comics as a Literary-Didactic Method and Their Use for Reducing Gender Differences in Reading Literacy at the Primary Level of Education
}

Maja KerneŽA ${ }^{\star 1}$ AND KaTja KoŠIR ${ }^{2}$

$\approx \quad$ The aim of the present study was to examine the effect of the systematic use of comics as a literary-didactic method to reduce gender differences in reading literacy and reading motivation at the primary level of education. It was assumed that the use of comics would have a positive effect on pupils' reading literacy and reading motivation, while also reducing the aforementioned differences between boys and girls. The dimensions of reading literacy and reading motivation were examined in experimental and control groups, before and after the intervention, by means of questionnaires and tests for pupils. The sample consisted of 143 pupils from second to fifth grade from two Slovenian primary schools in a rural environment, of which 73 pupils participated in the experimental group and 70 pupils represented the control group. Effects of the use of comics as a literary-didactic method were not found: using comics as a literary-didactic method did not have a statistically significant effect on pupils' reading literacy and reading motivation. However, when the four-way structure of the research (taking into account the age and gender of the pupils) was considered, some subgroups showed a statistically significant increase in reading interest and attitude towards reading. No reduction of gender differences in reading literacy and reading motivation was found. Based on the results, guidelines for further research are established and suggestions are offered for teachers' work.

Keywords: comics, gender differences, primary level pupils, reading literacy, reading motivation 


\section{Strip kot literarnodidaktična metoda dela in njegova uporaba za zmanjšanje razlik med spoloma v bralni pismenosti na razredni stopnji šolanja}

Maja Kerneža in Katja Košir

$\propto$ Namen prispevka je preveriti učinke sistematične uporabe stripa kot literarnodidaktične metode dela na zmanjšanje razlik med spoloma $\mathrm{v}$ bralni pismenosti na razredni stopnji šolanja. Predvidevali smo, da bo uporaba stripa pozitivno vplivala na bralno pismenost učencev in njihovo motivacijo za branje, hkrati pa zmanjšala razlike v navedenih spremenljivkah med spoloma. Izbrane dimenzije bralne pismenosti in bralne motivacije so bile pred intervencijo in po njej v eksperimentalni in kontrolni skupini preverjane s pomočjo vprašalnikov in testov za učence ter ocenjevalne lestvice za učitelje. V raziskavo je bilo vključenih 143 učencev od 2. do 5. razreda dveh slovenskih osnovnih šol iz podeželskega okolja, od katerih je 73 učencev sodelovalo v eksperimentalnem delu raziskave, 70 učencev pa je predstavljalo kontrolno skupino. V izvedeni raziskavi uporaba stripa kot literarnodidaktične metode dela v okviru zastavljenih hipotez ni imela statistično pomembnega učinka na bralno pismenost in bralno motivacijo učencev. Ko smo upoštevali štirismerno strukturo raziskave, pa se je strip kot literarnodidaktična metoda dela v nekaterih podskupinah udeležencev (upoštevajoč starost in spol učencev) pokazal kot primeren za zviševanje zanimanja za branje in izboljšanje odnosa do branja. Do pomembnega zmanjšanja razlik med spoloma ni prišlo v nobenem primeru. Na podlagi rezultatov v sklepnem delu predstavljamo predloge za nadaljnje raziskave in smernice za učiteljevo delo.

Ključne besede: strip, razlike med spoloma, učenci razredne stopnje, bralna pismenost, bralna motivacija 


\section{Introduction}

International studies assessing pupils' knowledge show differences between genders in various fields of education, thus encouraging the exploration of gender differences in reading and reading literacy (e.g., Below, Skinner, Fearrington \& Sorrell, 2010; Lynn \& Mikk, 2009). The latest results in the most notable educational studies, PISA and PIRLS, are as follows: PISA (pupils in the transition from primary to secondary school) shows Slovenian pupils achieving lower results than the OECD average (scoring 481 points, compared to the OECD average of 496 points), while the difference between genders is higher than the OECD average (girls average: 510 points, boys average: 454 points). The results have deteriorated in comparison with surveys conducted in previous years (Štraus, Šterman Ivančič \& Štigl, 2013). PIRLS (fourth grade primary school pupils) also reveals the difference between genders in reading literacy. In the most recent test, girls achieved 16 points more than their male peers, which is also the average difference between genders in other participating countries. Compared to previous years, however, the results show that reading literacy among Slovenian pupils is increasing, with girls achieving higher performance in each year of Slovenian participation in the survey (Doupona Horvat, 2012; Prvi rezultati PIRLS 2011, n. d.).

Pupils' academic achievement, as well as literacy, is influenced by many factors (Sheridan et al., 2011). Based on the results of PIRLS, Martin, Mullis and Kennedy (2007) highlight the important factors affecting pupils' literacy: early educational activities and resources at home, parents' attitudes towards reading and their perception of the school environment, reading for homework, the availability of school resources, family-school interaction, principals' perception of the school climate and safety, teachers' satisfaction with their career, school safety, pupils' attitudes towards reading and their reading self-concept. Based on PISA results, Puklek Levpušček, Podlesek and Šterman Ivančič (2012) highlight the importance of school, the education programme, language spoken at home, and pupils' attitudes towards reading, as well as their frequency of reading activity and computer usage. The above studies also emphasise pupils' psychological characteristics as well as environmental factors, especially those related to the family, school and libraries.

The impact of school on reading literacy begins in kindergarten, when most children enter the education system (Linklater, O'Connor \& Palardy, 2009), and continues on entering school, where teachers affect pupils' achievements with their attitudes (Graziano, Reavis, Keane \& Calkins, 2007), competences (Cadima, Leal \& Burchinal, 2010; Hall, Johnson, Juzwik, Wortham 
\& Mosley, 2010) and knowledge (Grosman, 2006). Teachers seeking to reduce the difference between genders in reading literacy should continuously educate themselves about new reading and teaching strategies and new learning styles, reflect on their way of teaching, work on pupils' individual strengths, accept boys' preferences and provide male role models (Lester Taylor, 2004).

Pupils' reading motivation depends on multiple motivational factors that encourage reading (Guthrie \& Alao, 1997; Guthrie, Wigfield \& VonSecker, 2000; Stipek, 1996), including teachers, family, friends, books, environment, activities (Ulper, 2011), reading technique, reading comprehension level, reading interest (Kramarič, Ropič \& Urbančič Jelovšek, 2000), predispositions, beliefs and goals (Conradi Gee Jang \& McKenna, 2014). By fostering intrinsic reading motivation, teachers encourage lifelong reading (Bucik, 2009) and contribute to a higher level of reading and increased academic achievement (Pečjak, Bucik, Gradišar \& Peklaj, 2006). Pupils who are more intrinsically motivated and competent at reading have teachers who use diverse reading materials, encourage reading and discussion about content, include reading in lessons and regularly read in class, promote reading in the classroom, and give pupils a choice of reading materials (Pečjak \& Košir, 2004).

Although reading education is a goal of all school subjects, Slovenian pupils start learning to read systematically in Slovene language classes, which, at primary level in the first and second grades of the first educational period, begin as literacy training with systematic reading and writing technique acquisition. In the third grade, this continues via improvement and consolidation, and is then further promoted in the second educational period in an upgraded form, supplemented by receiving, parsing and evaluating spoken and written literary and non-literary texts (Poznanovič Jezeršek et al., 2011). Teaching literature is based on the communication model of literature education, according to which learning to read and write is a long process. In this process, pupils begin to read children's literature by themselves when their reading fluency reaches a level whereby their desire to find out the end of the story is stronger than their desire to avoid reading (Kordigel Aberšek, 2008). In the first educational period, the teacher and pupils should take as much time as the pupils needs to acquire the aforementioned skills (Kordigel \& Saksida, 1999), while in the second educational period, the teacher should maintain and develop the pupils' interest in literary texts (Krakar Vogel et al., 2005). With the activities before, during and after reading, the communication model leads the reader from spontaneous to reflexive reception of literary texts (Kordigel, 1999).

When working with a literary text, teachers can use graphic organisers that enable the illustration of the relationship between text signals, i.e., groups of 
content based on similarity or dissimilarity, hierarchies, relationships between the whole and the parts, chronological orders, and causal relationship (Kordigel Aberšek, 2008). This can be done with thematic illustrations, structured overviews, semantic networks, episodic maps, concept maps (Horton, Lovitt \& Bergerud, 1990), curves, lines, flowcharts, circles, ellipses and speech balloons as used in comics (Kordigel Aberšek, 2008). A combination of visual and verbal information helps pupils to create their own meaning of the text (Crane Williams, 2008). When using comics in the classroom, pupils are allowed to create their own stories, including characterisation, scenes, actions, problems and solutions to problems (Lyga, 2006). When pupils work with and design their own comics, they carefully apply learned strategies, define the main tasks, summarise their knowledge, and display information in an educational and entertaining way, as well as exploring the use of dialogue, dramatic dialogue, conciseness and nonverbal communication, while simultaneously enhancing linguistic and artistic skills (Morrison, Bryan \& Chilcoar, 2002), their writing and handwriting (Bitz, 2004).

Comics are one of the non-traditional literary genres that has a particular appeal for boys (Sadowski, 2010). Comics draw readers into the world they are reading about and enable them to mingle with the characters, who appear real to the readers. This attracts boys to read and has an impact on their interest in reading, their immersion and their feeling of competence (McCloud, 2010), which are the most important components of reading comprehension in boys (Pečjak, Bucik, Peštaj, Podlesek and Pirc, 2010).

\section{The present study}

Originating from the theoretical foundations and empirical findings reported above, the aim of the present study was to systematically investigate comics as a literary-didactic method to reduce gender differences in reading literacy and reading motivation at the primary level of education. In view of the results of existing studies that examine the use of comics in the classroom, but that do not investigate the use of comics as a literary-didactic method and do not cover the primary level of education, we predicted that the use of comics in the classroom would have a positive effect on pupils' reading literacy and reading motivation. This premise was systematically examined through the structured inclusion of comics in Slovene language and art instruction.

Reading literacy was assessed using two distinctive measures - as reading comprehension and as the ability to perceive text incoherence - while reading motivation was operationalised as interest in reading literary texts, 
perception of reading as a difficult activity, and attitude towards reading literary texts. Due to the structure of the questionnaire, the dimensions of interest in reading literary texts and perception of reading as a difficult activity were named motivation for reading literary texts; however, it should be noted that the dimension of pupils' attitude towards reading also represents an aspect of reading motivation, and is therefore discussed as such when presenting and interpreting the results. Distinguishing between various dimensions of reading motivation contributes to clearer and more precise results (Baker, 2003; Mazzoni, Gambrell \& Korkeamaki, 1999).

Originating from the general aims of the study, the following hypotheses were tested:

H1: The use of comics as a literary-didactic method is effective in reducing the gender differences in reading literacy at the primary level of education.

H2: The use of comics as a literary-didactic method is effective in raising overall literacy at the primary level of education.

$\mathrm{H}_{3}$ : With the use of comics as a literary-didactic method, the gender differences in motivation for reading literary texts at the primary level of education can be reduced.

$\mathrm{H}_{4}$ : The use of comics as a literary-didactic method contributes to raising the overall motivation for reading literary texts at the primary level of education.

$\mathrm{H}_{5}$ : With the use of comics as a literary-didactic method, the gender differences in attitude towards reading literary texts at the primary level of education can be reduced.

H6: Comics as a literary-didactic method is effective in improving the overall attitude towards reading literary texts at the primary level of education.

\section{Method}

\section{Participants and procedure}

Using a convenient sampling procedure, 143 pupils from eight classes in two primary schools from the rural environment participated in the study, including two second-grade classes ( 32 pupils), two third-grade classes (35 pupils), two fourth-grade classes (33 pupils), and two fifth-grade classes (43 pupils). In both schools, two classes (second and third grade in school 1, and fourth and fifth grade in school 2) represented the experimental group (73 pupils) and two classes (fourth and fifth grade in school 1, and second and third grade in school 
2) were the control group (7o pupils). A total of 76 of the participating pupils were boys ( 41 in the experimental group and 35 in the control group), while 67 were girls ( 32 in the experimental group and 35 in the control group).

The study design was quasi-experimental, using both qualitative and quantitative research methods, and was conducted in three phases:

1. An initial evaluation of pupils' reading literacy and their reading motivation was conducted in both the experimental and control groups before the implementation of the intervention.

2. The evaluation was followed by the implementation of a programme in which the new factor of comics as a literary-didactic method entered the existing educational practice in Slovene lessons and art classes.

3. A final evaluation of pupils' reading literacy and reading motivation was conducted at the end of the experiment for all participants.

The intervention lasted for approximately seven weeks (depending on the inclusion of lessons in the annual work plan) and was delivered during eight units, at 19 Slovene and art lessons. A detailed arrangement of the programme, with lesson numbers, arrangement of lessons and the aims of the lessons, is presented in Table 1.

A short educational programme and training was conducted for the teachers involved in the experimental part of the programme. In the first part, they were introduced to comics as a literary-didactic method, then, in the second part, they were familiarised with a detailed lesson plan, designed as a manual (one version for the second and third grades, and another version for the fourth and fifth grades, the differences being mainly due to the difficulty of the selected texts, not due to the content itself). The third part of the training was conducted individually, so that any questions about the lesson plan could be addressed. The training for each individual teacher lasted six hours. During the implementation of the programme, the research team was available to the teachers for consultation; however, none of the teachers required additional help, since comics as a literary-didactic method had been presented to them thoroughly in the first phase of the training.

In the control group, the teachers taught according to the annual work plan set at the beginning of the school year. If teachers from the control group had comics in any form planned during the time of the intervention, they were asked to move this unit to a time after the completion of the study. Furthermore, the control group teachers were instructed that any ideas obtained by observing their colleagues who had participated in the experimental part of the research may only be used in their work after the completion of the survey. 
Table 1. Detailed arrangement of the programme, with lesson numbers, arrangement of lessons and the aims of the lessons.

\begin{tabular}{lll}
\hline Lesson number & Class & Aim \\
\hline 1,2 & Slovene & Pupils get to know comics and their basic characteristics. \\
\hline 3 & Slovene & Pupils independently explore and learn about comics. \\
\hline 4,5 & Slovene & $\begin{array}{l}\text { Pupils learn about various displays of text in comics, about } \\
\text { meaning and the use of speech bubbles in comics, and about } \\
\text { distinguishing which part of the text can be displayed with } \\
\text { writing and which part of the text can be displayed visually. }\end{array}$ \\
\hline 6,7 & Art & $\begin{array}{l}\text { Pupils learn the steps of creating comics, which they then use } \\
\text { in creating their first comic. }\end{array}$ \\
\hline 10,9 & Art & $\begin{array}{l}\text { For the first time, pupils work with comics completely inde- } \\
\text { pendently. They draw a comic scene using a given text. They } \\
\text { practise determining which part of the text to show with text } \\
\text { and which part to show visually. }\end{array}$ \\
\hline $12,13,14,15$ and & Slovene & $\begin{array}{l}\text { By making a comic, pupils determine the incoherence in a given } \\
\text { text. }\end{array}$ \\
\hline $16,17,18,19$ & and Art & $\begin{array}{l}\text { The use of comics as a literary-didactic method to increase } \\
\text { pupils' literacy and reading motivation focuses on: motivation } \\
\text { to read literary texts, active work with text, engaging with the } \\
\text { deeper meaning of the text, detection of several text elements, } \\
\text { creating comics using a given text, determining which part } \\
\text { of the text to show with text and which part to show visually, } \\
\text { actively working with text using a planning sheet, indepen- } \\
\text { dently and coherently following the original story and the order } \\
\text { of events. }\end{array}$ \\
\hline
\end{tabular}

Note: The use of comics has a great motivational power per se (Norton, 2003; Schwarz, 2002, 2006; Versaci, 2001), which is why we do not specifically list reading motivation as an aim of the first seven units presented in the above table.

\section{Measures}

All of the data were obtained before and after the implementation of the intervention, both in the experimental group and the control group. A reading literacy test and a questionnaire measuring pupils' attitude towards reading literature and their motivation to read literary texts were used to assess the variables included in the study. These data were triangulated using teachers' reports of the pupils' literacy level, their attitude towards reading and their reading motives.

Reading literacy (two-part test): The first part of the test, verifying the pupils' reading comprehension, was adapted according to Mueller's test (1969; as cited in Pečjak, 1999). The number of tasks varied for each age group, with each task having two sub-questions. For each correct answer, the pupils received one point (number of tasks/maximum number of points: second grade: 
$3 / 6$, third grade: $5 / 10$, fourth and fifth grade: $10 / 20$ ). Due to the unequal maximum number of points with regard to the class level, the results were standardised within each class using $\mathrm{z}$-scores. The second part of the test, examining the ability to perceive text incoherence, consisted of three tasks. An incoherent sentence was added to a passage of an original literary text, and the pupils were asked to find and underline it. The literary texts were identical for fourth- and fifth-grade pupils, while the texts differed for the second and third grades. Each correctly solved task earned the pupil one point. The maximum number of points for all test versions was three; a higher score indicates a higher expression of the variable.

Reading motivation (two-part questionnaire): The first part of the questionnaire, examining pupils' attitude towards reading via ten questions, was based on a questionnaire by McKenna and Kear (1990; as cited in Pečjak, 1999). Pupils evaluated ten statements, ranging on a four-point scale ( 1 - very bad, 4 - very good). The maximum number of points was 40, whereby a higher score indicates a higher expression of the variable. The reliability of the questionnaire (Cronbach's alpha) was 0.79 for the first measurement and 0.87 for the second measurement. The second part of the questionnaire, adapted from a questionnaire by Pečjak et al. (2006), consisted of 14 items that measured two dimensions of pupils' motivation to read literary texts on a three-point scale ( 1 - not true, 3 - true). Ten items were intended to measure interest in reading literary texts, and four items represented a measure of perception of reading as a difficult activity. The reliability coefficient (Cronbach's alpha) for the dimension of interest in reading literary texts was 0.78 for the first measurement and 0.83 for the second measurement, and for the dimension perception of reading as a difficult activity was 0.52 for the first measurement and 0.33 for the second measurement. The maximum number of points was 30 ; a higher score indicates a higher expression of the variable.

Teacher's report (three-part questionnaire): A five-point scale was designed in order to obtain the teacher's evaluation of the pupils' level of literacy ( 1 - the pupil's reading comprehension is very poor, 5 - the pupil's reading comprehension is excellent), their attitude towards reading ( 1 - the pupil has a strong aversion to reading, 5 - the pupil is very fond of reading) and their motivation to read literary texts. The scale for the evaluation of reading motivation was formed on the basis of eight goals pupils reported as reasons for reading, as reported by Sweet and Guthrie (1996): involvement, curiosity, recognition, work avoidance, challenge, social interaction, compliance and competition. Teachers validated statements for individual pupil's on a five-point scale ( 1 - the claim does not apply to the designated pupil, 5 - the claim applies strongly to 
the designated pupil). As only teachers who were not included in the intervention programme returned completed questionnaires, more detailed analyses of teacher evaluations were not conducted.

\section{Results}

In order to determine the effect of comics as a literary-didactic method to reduce the gender differences in pupils' reading literacy and reading motivation at the primary level of education, the effect of pupils' inclusion in the quasiexperimental programme on aspects of reading literacy and reading motivation was investigated. Correlations between dependent variables are presented in Table 2 and correlations between variables included in the study with regard to gender are presented in Table 3. The correlations between variables for the first measurement are presented below the diagonal and the correlations for the second measurement above the diagonal.

Table 2. Correlations between dependent variables included in the study.

\begin{tabular}{lcccccc}
\hline & 1. & 2. & 3. & 4. & 5. & Test-retest \\
\hline 1. Comprehension & - & $0.30^{* *}$ & 0.09 & 0.00 & $-0.27^{* *}$ & $0.44^{* *}$ \\
2. Incoherence & $0.38^{* *}$ & - & 0.02 & 0.02 & -0.09 & $0.20^{*}$ \\
3. Attitude & 0.11 & 0.08 & - & $0.52^{* *}$ & -0.10 & $0.62^{* *}$ \\
4. Interest & -0.04 & 0.07 & $0.61^{* *}$ & - & -0.02 & $0.55^{* *}$ \\
5. Difficult activity & -0.20 & 0.01 & 0.01 & -0.00 & - & 0.12 \\
\hline
\end{tabular}

Note: 1. Comprehension: pupils' reading comprehension. 2. Incoherence: pupils' ability to perceive text incoherence. 3. Attitude: pupils' attitude towards reading literary texts. 4. Interest: pupils' interest in reading literary texts. 5. Difficult activity: perception of reading as a difficult activity. Test-retest: correlation within variables between the first and second measurement.

As seen in Table 2, the dependent variables are mostly positively correlated, with the exception of the correlation between variables regarding perception of reading as a difficult activity and reading comprehension, which are moderately negatively related. The test-retest correlations are statistically significant and positive, except in the case of perception of reading as a difficult activity. The test-retest correlation within the pupils' ability to perceive text incoherence is low, while the test-retest correlation for the pupils' reading comprehension and interest in reading literary texts is moderate. The correlation within attitude towards reading literary texts between the test and the retest is high. Due to various indicators that question the reliability and validity of the measure perception of reading as a difficult activity (inadequate internal 
consistency coefficient, low test-retest correlation, negative correlation with reading comprehension), this measure was eliminated from further analyses. Pupils with a higher score in the reading comprehension test also achieved a higher score in a test of ability to perceive text incoherence on both measurements. Similarly, on both measurement points, a better attitude towards reading is reported by pupils with a higher level of interest in reading.

Table 3. Correlations between variables included in the study with regard to gender.

\begin{tabular}{llccccc}
\hline & & 1. & 2. & 3. & 4. & 5. \\
\hline 1. Comprehension & Boys & - & $0.32^{*}$ & 0.17 & 0.22 & $-0.25^{*}$ \\
& Girls & - & $0.31^{*}$ & 0.07 & 0.20 & -0.05 \\
\hline 2. Incoherence & Boys & $0.49^{* *}$ & - & 0.02 & 0.15 & -0.17 \\
& Girls & $0.27^{*}$ & - & 0.18 & 0.15 & -0.23 \\
\hline 3. Attitude & Boys & 0.23 & 0.12 & - & $0.75^{* *}$ & -0.02 \\
& Girls & -0.11 & 0.00 & - & $0.65^{* *}$ & $-0.37^{* *}$ \\
\hline 4. Interest & Boys & 0.19 & 0.13 & $0.68^{* *}$ & - & -0.12 \\
& Girls & -0.01 & -0.09 & $0.44^{* *}$ & - & $-0.27^{*}$ \\
\hline \multirow{2}{*}{ 5. Difficult activity } & Boys & 0.00 & 0.07 & 0.11 & 0.02 & - \\
& Girls & -0.01 & -0.04 & -0.11 & -0.04 & - \\
\hline
\end{tabular}

Note: 1. Comprehension: pupils' reading comprehension. 2. Incoherence: pupils' ability to perceive text incoherence. 3. Attitude: pupils' attitude towards reading literary texts. 4. Interest: pupils' interest in reading literary texts. 5. Difficult activity: perception of reading as a difficult activity.

As seen in Table 3, the variables are mostly positively correlated, with the exception of the correlation between variables regarding girls' interest in reading literary texts and both genders' perception of reading as a difficult activity.

Both genders showed a statistically significant and positive correlation between reading comprehension and the ability to perceive text incoherence on first measurement. Pupils with a higher score in the reading comprehension test also achieved higher results in the test of ability to perceive text incoherence on both measurements. The correlation between variables was stronger for boys than for girls. On the second measurement, the strength of correlations almost equalised, with a lower correlation for boys and a stronger correlation for girls.

Pupils with a better attitude towards reading literary texts showed a higher level of interest in reading literary texts on both measurements. The correlation between pupils' interest in reading literary texts and their attitude 
towards reading increased between measurements for both genders.

The correlation between reading comprehension and perception of reading as a difficult activity is almost the same for girls on both measurements, while there is a decrease in the correlation among boys on second measurement, which shows that boys with better reading comprehension perceived reading as a difficult activity less often.

The correlation between girls' attitude towards reading and their perception of reading as a difficult activity was negative and stronger on second measurement: girls who showed a better attitude towards reading perceived reading as a difficult activity less often. While there was also an improvement among boys, the correlation is not statistically significant.

Similarly, the correlation between girls' interest in reading and their perception of reading as a difficult activity is negative and stronger on second measurement. Girls who showed a higher interest in reading perceived reading as a difficult activity less often, while the correlation is not statistically significant for boys.

The effects of using comics as a literary-didactic method on the aspects of reading literacy and reading motivation were studied using a four-way repeated measures ANOVA and a Bonferroni post hoc test with regard to measurement period, inclusion in the programme, gender and classroom (age group) level.

\section{Reading literacy}

Reading literacy was operationalised using two variables: reading comprehension and the ability to perceive text incoherence. The average values and standard deviations of reading comprehension for the experimental group and control group before and after the implementation of the programme can be found in Table 4, while the average values and standard deviations of pupils' ability to perceive text incoherence are presented in Table 5. 
Table 4. Descriptive statistics for reading literacy - reading comprehension test - with regard to measurement point (before/after the implementation of the programme), condition (control/experimental), gender and class.

\begin{tabular}{|c|c|c|c|c|c|c|c|c|c|c|c|c|c|}
\hline \multirow{3}{*}{ Gender } & \multirow{3}{*}{ Class } & \multicolumn{6}{|c|}{ Before } & \multicolumn{6}{|c|}{ After } \\
\hline & & \multicolumn{3}{|c|}{ M } & \multicolumn{3}{|c|}{ SD } & \multicolumn{3}{|c|}{ M } & \multicolumn{3}{|c|}{ SD } \\
\hline & & EG & CG & Total & EG & CG & Total & EG & CG & Total & EG & CG & Total \\
\hline \multirow{5}{*}{ Boys } & 2 & -0.41 & 0.28 & -0.02 & 1.17 & 0.96 & 1.08 & -0.21 & -0.38 & -0.31 & 1.07 & 1.55 & 1.32 \\
\hline & 3 & 0.19 & -0.90 & -0.41 & 0.53 & 1.21 & 1.09 & 0.43 & -0.48 & -0.07 & 0.49 & 1.57 & 1.27 \\
\hline & 4 & 0.13 & 0.21 & 0.16 & 0.73 & 0.68 & 0.70 & -0.14 & 0.25 & -0.01 & 1.15 & 0.70 & 1.02 \\
\hline & 5 & 0.10 & -0.37 & -0.10 & 1.12 & 1.15 & 1.18 & 0.20 & -0.53 & -0.11 & 0.68 & 1.14 & 0.96 \\
\hline & Total & 0.04 & -0.27 & -0.10 & 0.94 & 1.13 & 1.04 & 0.07 & -0.34 & -0.12 & 0.90 & 1.32 & 1.12 \\
\hline \multirow{5}{*}{ Girls } & 2 & 0.35 & -0.31 & 0.02 & 1.08 & 0.95 & 0.31 & 0.26 & 0.35 & 0.95 & 0.39 & 0.35 & 0.36 \\
\hline & 3 & 0.63 & 0.48 & 0.55 & 1.09 & 0.40 & 0.10 & 0.16 & 0.05 & 0.48 & 0.53 & 0.45 & 0.47 \\
\hline & 4 & 0.52 & -0.25 & 0.26 & 0.70 & 0.52 & -0.07 & 0.26 & -0.25 & 0.57 & 0.71 & 1.39 & 1.18 \\
\hline & 5 & -0.48 & 0.45 & -0.60 & 1.18 & 0.51 & 0.16 & 0.10 & 0.23 & 1.26 & 1.00 & 0.92 & 0.94 \\
\hline & Total & 0.13 & 0.10 & 0.11 & 1.04 & 0.70 & 0.14 & 0.18 & 0.09 & 0.94 & 0.72 & 0.89 & 0.81 \\
\hline \multirow{5}{*}{ Total } & 2 & -0.01 & 0.01 & 0.00 & 1.06 & 0.97 & 1.00 & 0.40 & -0.03 & 0.00 & 0.80 & 1.18 & 1.00 \\
\hline & 3 & 0.38 & -0.32 & 0.00 & 0.58 & 1.17 & 1.00 & 0.31 & -0.26 & 0.00 & 0.51 & 1.23 & 1.00 \\
\hline & 4 & 0.24 & -0.07 & 0.10 & 0.65 & 0.61 & 0.64 & -0.02 & -0.05 & -0.35 & 1.05 & 1.15 & 1.08 \\
\hline & 5 & -0.19 & 0.06 & -0.78 & 1.39 & 0.94 & 1.21 & 0.15 & -0.13 & 0.03 & 0.84 & 1.07 & 0.95 \\
\hline & Total & 0.08 & -0.08 & 0.00 & 1.03 & 0.95 & 0.99 & 0.12 & -0.12 & 0.00 & 0.82 & 1.14 & 0.99 \\
\hline
\end{tabular}

Note: EG: experimental group; CG: control group. 
Table 5. Descriptive statistics for reading literacy - pupils' ability to perceive text incoherence test - with regard to measurement point (before/after the implementation of the programme), condition (control/experimental), gender and class.

\begin{tabular}{|c|c|c|c|c|c|c|c|c|c|c|c|c|c|}
\hline \multirow{3}{*}{ Gender } & \multirow{3}{*}{ Class } & \multicolumn{6}{|c|}{ Before } & \multicolumn{6}{|c|}{ After } \\
\hline & & \multicolumn{3}{|c|}{ M } & \multicolumn{3}{|c|}{ SD } & \multicolumn{3}{|c|}{ M } & \multicolumn{3}{|c|}{ SD } \\
\hline & & EG & CG & Total & EG & CG & Total & EG & CG & Total & EG & CG & Total \\
\hline \multirow{5}{*}{ Boys } & 2 & 2.20 & 1.13 & 1.54 & 1.30 & 0.84 & 1.13 & 2.00 & 2.13 & 2.08 & 0.71 & 1.36 & 1.12 \\
\hline & 3 & 1.50 & 0.25 & 0.88 & 1.00 & 0.50 & 0.99 & 1.50 & 2.75 & 2.13 & 1.29 & 0.50 & 1.13 \\
\hline & 4 & 0.89 & 1.00 & 0.92 & 0.78 & 0.00 & 0.67 & 0.78 & 1.00 & 0.83 & 1.30 & 1.73 & 1.34 \\
\hline & 5 & 1.00 & 0.83 & 0.92 & 0.63 & 0.75 & 0.67 & 0.50 & 1.00 & 0.75 & 0.55 & 1.10 & 0.87 \\
\hline & Total & 1.29 & 0.86 & 1.09 & 1.00 & 0.73 & 0.90 & 1.08 & 1.76 & 1.40 & 1.14 & 1.34 & 1.27 \\
\hline \multirow{5}{*}{ Girls } & 2 & 1.57 & 1.13 & 1.33 & 0.98 & 0.99 & 0.98 & 1.86 & 1.75 & 1.80 & 1.0 & 1.17 & 1.08 \\
\hline & 3 & 2.00 & 0.67 & 1.50 & 1.23 & 0.58 & 1.20 & 1.80 & 3.00 & 2.25 & 0.94 & 0.00 & 0.97 \\
\hline & 4 & 1.20 & 0.60 & 0.90 & 1.10 & 0.55 & 0.88 & 1.80 & 2.00 & 1.90 & 1.64 & 1.41 & 1.45 \\
\hline & 5 & 1.29 & 1.70 & 1.53 & 0.49 & 0.71 & 0.64 & 1.71 & 1.38 & 1.53 & 1.38 & 1.42 & 1.36 \\
\hline & Total & 1.50 & 1.17 & 1.33 & 0.93 & 0.87 & 0.91 & 1.79 & 1.83 & 1.81 & 1.18 & 1.27 & 1.21 \\
\hline \multirow{5}{*}{ Total } & 2 & 1.83 & 1.13 & 1.43 & 1.12 & 0.89 & 1.03 & 1.92 & 1.94 & 1.93 & 0.90 & 1.24 & 1.09 \\
\hline & 3 & 1.78 & 0.43 & 1.19 & 1.09 & 0.54 & 1.11 & 1.67 & 2.86 & 2.19 & 1.00 & 0.38 & 0.98 \\
\hline & 4 & 1.00 & 0.75 & 0.91 & 0.88 & 0.46 & 0.75 & 1.14 & 1.62 & 1.32 & 1.46 & 1.51 & 1.46 \\
\hline & 5 & 1.15 & 1.36 & 1.26 & 0.56 & 0.84 & 0.71 & 1.15 & 1.21 & 1.19 & 1.21 & 1.25 & 1.21 \\
\hline & Total & 1.40 & 1.02 & 1.22 & 0.96 & 0.81 & 0.91 & 1.44 & 1.80 & 1.61 & 1.20 & 1.29 & 1.25 \\
\hline
\end{tabular}

Note: EG: experimental group; CG: control group.

The results reported in Table 4 show that the boys in the fifth grade in the experimental group and second and fourth grades of the control group exhibited a higher level of reading comprehension than girls.

In order to determine the statistical significance of the differences between the experimental and control groups with regard to changes in dependent variables between both measurement points, a repeated measures ANOVA was conducted, taking pupils' gender and class as potential mediators. The interaction between the measurement period and inclusion in the programme represents a measure of the overall impact of the programme; all further interactions were used to investigate the moderating role of gender and class in the relationship between the dependent and independent variables. 
Table 6. Repeated measures ANOVA results: the effect of using comics as a literary-didactic method on pupils' reading comprehension.

\begin{tabular}{lcccc}
\hline & $\begin{array}{c}\text { Wilks' } \\
\text { Lambda }\end{array}$ & df & F & p \\
\hline Measurement * inclusion & 1.00 & 1,127 & 0.07 & 0.80 \\
Measurement * inclusion * gender & 1.00 & 1,127 & 0.37 & 0.54 \\
Measurement * inclusion * class & 0.98 & 3,127 & 1.04 & 0.38 \\
Measurement * inclusion * gender * class & 0.96 & 3,127 & 1.74 & 0.16 \\
\hline
\end{tabular}

Note: Measurement: measurement period; inclusion: inclusion in the programme.

Table 7. Repeated measures ANOVA results: the effect of using comics as a literary-didactic method on pupils' ability to perceive text incoherence.

\begin{tabular}{lcccc}
\hline & $\begin{array}{c}\text { Wilks' } \\
\text { Lambda }\end{array}$ & df & F & p \\
\hline Measurement * inclusion & 0.90 & 1,127 & 14.84 & 0.30 \\
Measurement * inclusion * gender & 1.00 & 1,127 & 0.13 & 0.47 \\
Measurement * inclusion * class & 0.90 & 3,127 & 4.65 & 0.45 \\
Measurement * inclusion * gender * class & 0.98 & 3,127 & 0.84 & 0.48 \\
\hline
\end{tabular}

Note: Measurement: measurement period; inclusion: inclusion in the programme.

As can be seen from the results presented in Tables 6 and 7 , the effect of inclusion in the programme (measurement ${ }^{*}$ inclusion) is not significant for any of the aspects of reading literacy. Compared to the pupils in the control group, the pupils in the experimental group did not significantly improve their result in reading comprehension and incoherence perception tests.

\section{Interest in reading literature}

In addition, the effect of inclusion in the programme on pupils' interest in reading literary texts was examined. Descriptive statistics for this measure are presented in Table 8 . 
Table 8. Descriptive statistics for pupils' interest in reading literary texts questionnaire with regard to measurement point (before/after the implementation of the programme), condition (control/experimental), gender and class.

\begin{tabular}{|c|c|c|c|c|c|c|c|c|c|c|c|c|c|}
\hline \multirow{3}{*}{ Gender } & \multirow{3}{*}{ Class } & \multicolumn{6}{|c|}{ Before } & \multicolumn{6}{|c|}{ After } \\
\hline & & \multicolumn{3}{|c|}{$M$} & \multicolumn{3}{|c|}{ SD } & \multicolumn{3}{|c|}{$M$} & \multicolumn{3}{|c|}{ SD } \\
\hline & & EG & CG & Total & EG & CG & Total & EG & CG & Total & EG & CG & Total \\
\hline \multirow{5}{*}{ Boys } & 2 & 25.57 & 27.22 & 26.50 & 3.60 & 2.05 & 2.85 & 23.14 & 27.67 & 25.69 & 2.34 & 3.43 & 3.71 \\
\hline & 3 & 24.44 & 23.55 & 23.95 & 3.47 & 4.46 & 3.97 & 21.56 & 23.18 & 22.45 & 4.53 & 4.12 & 4.27 \\
\hline & 4 & 25.15 & 26.17 & 25.47 & 3.05 & 3.76 & 3.22 & 25.77 & 20.83 & 24.21 & 3.49 & 5.04 & 4.55 \\
\hline & 5 & 24.67 & 19.89 & 22.62 & 3.97 & 5.82 & 5.26 & 24.67 & 19.89 & 22.62 & 3.47 & 6.35 & 5.35 \\
\hline & Total & 24.93 & 24.00 & 24.50 & 3.38 & 5.00 & 4.20 & 24.07 & 23.09 & 23.62 & 3.81 & 5.49 & 4.65 \\
\hline \multirow{5}{*}{ Girls } & 2 & 27.13 & 27.63 & 27.38 & 2.03 & 2.92 & 2.45 & 25.00 & 27.88 & 26.44 & 4.34 & 2.10 & 3.63 \\
\hline & 3 & 25.71 & 27.88 & 26.87 & 2.98 & 1.96 & 2.64 & 22.57 & 27.13 & 25.00 & 3.31 & 2.03 & 3.51 \\
\hline & 4 & 28.60 & 26.00 & 26.93 & 1.14 & 2.69 & 2.56 & 27.60 & 25.44 & 26.21 & 1.67 & 2.88 & 2.67 \\
\hline & 5 & 27.67 & 24.90 & 26.41 & 29 & 1.73 & 2.79 & 28.42 & 21.60 & 25.32 & 1.68 & 4.14 & 4.57 \\
\hline & Total & 27.25 & 26.49 & 26.85 & 2.60 & 2.57 & 2.60 & 26.16 & 25.29 & 25.70 & 3.65 & 3.83 & 3.74 \\
\hline \multirow{5}{*}{ Total } & 2 & 26.40 & 27.41 & 26.94 & 2.87 & 2.43 & 2.65 & 24.13 & 27.76 & 26.06 & 3.56 & 2.82 & 3.64 \\
\hline & 3 & 25.00 & 25.37 & 25.20 & 3.22 & 4.17 & 3.72 & 22.00 & 24.84 & 23.54 & 3.95 & 3.88 & 4.11 \\
\hline & 4 & 26.11 & 26.07 & 26.10 & 3.07 & 3.03 & 3.00 & 26.28 & 23.60 & 25.06 & 3.16 & 4.39 & 3.94 \\
\hline & 5 & 26.17 & 22.53 & 24.56 & 3.69 & 4.81 & 4.55 & 26.54 & 20.89 & 24.00 & 3.28 & 5.22 & 5.09 \\
\hline & Total & 25.95 & 25.24 & 25.60 & 3.26 & 4.14 & 3.72 & 24.99 & 24.19 & 24.59 & 3.86 & 4.83 & 4.36 \\
\hline
\end{tabular}

Note: EG: experimental group; CG: control group.

The effect of the use of comics as a literary-didactic method at the primary level of education was examined using a repeated measures ANOVA and a Bonferroni post hoc test.

Table 9. Repeated measures ANOVA results: the effect of using comics as a literary-didactic method on pupils' interest in reading literary texts.

\begin{tabular}{lcccc}
\hline & $\begin{array}{c}\text { Wilks' } \\
\text { Lambda }\end{array}$ & df & F & p \\
\hline Measurement * inclusion & 1.00 & 1,127 & 0.01 & 0.91 \\
Measurement * inclusion * gender & 1.00 & 1,127 & 0.11 & 0.74 \\
Measurement * inclusion * class & 0.90 & 3,127 & 4.95 & 0.00 \\
Measurement * inclusion * gender * class & 0.94 & 3,127 & 2.85 & 0.04 \\
\hline
\end{tabular}

Note: Measurement: measurement period; inclusion: inclusion in the programme. 
Table 9 shows a statistically significant interaction effect between inclusion in the programme, measurement period and class, as well as between measurement period, gender and class. The Bonferroni post hoc test showed a statistically significant difference between second- and third-grade pupils ( $\mathrm{p}=$ $\mathrm{0.02})$, as well as between second- and fifth-grade pupils $(\mathrm{p}=0.01)$. The results in Table 8 show that second-grade pupils achieved better results than thirdgrade pupils, and fifth-grade pupils achieved better results than second-grade pupils. The repeated measures ANOVA and the results presented in Table 8 show that fourth-and fifth-grade pupils in the experimental group reported a significantly improved level of interest in reading literary texts than their peers in the control group, while the results of second- and third-grade pupils indicate an improved level of interest in the control group. The differences between measurements, taking into account class as well as gender, show an improvement in the results among fourth-grade boys and among both genders in the fifth grade, but not among other participants in the experimental group.

\section{Attitude towards reading}

The effect of the use of comics in the classroom was also examined in the context of pupils' attitude towards reading literary texts. Descriptive statistics for this measure are shown in Table 10.

Table 10. Descriptive statistics for pupils' attitude towards reading literary texts questionnaire with regard to measurement point (before/after the implementation of the programme), condition (control/experimental), gender and class.

\begin{tabular}{|c|c|c|c|c|c|c|c|c|c|c|c|c|c|}
\hline \multirow{3}{*}{ Gender } & \multirow{3}{*}{ Class } & \multicolumn{6}{|c|}{ Before } & \multicolumn{6}{|c|}{ After } \\
\hline & & \multicolumn{3}{|c|}{ M } & \multicolumn{3}{|c|}{ SD } & \multicolumn{3}{|c|}{ M } & \multicolumn{3}{|c|}{ SD } \\
\hline & & EG & CG & Total & EG & CG & Total & EG & CG & Total & EG & CG & Total \\
\hline \multirow{5}{*}{ Boys } & 2 & 32.43 & 34.89 & 33.81 & 2.82 & 3.06 & 3.12 & 31.43 & 37.00 & 34.56 & 4.24 & 2.69 & 3.38 \\
\hline & 3 & 31.00 & 32.27 & 31.70 & 5.36 & 5.27 & 5.21 & 27.67 & 30.27 & 29.10 & 4.80 & 6.28 & 5.68 \\
\hline & 4 & 32.08 & 32.33 & 32.10 & 5.20 & 2.42 & 4.43 & 33.54 & 27.17 & 31.53 & 5.21 & 4.54 & 5.75 \\
\hline & 5 & 32.17 & 27.33 & 30.10 & 2.29 & 9.12 & 6.50 & 29.91 & 24.33 & 26.10 & 6.32 & 6.60 & 9.00 \\
\hline & Total & 31.93 & 31.69 & 31.82 & 4.09 & 6.23 & 4.15 & 30.10 & 29.94 & 30.03 & 7.32 & 7.03 & 7.14 \\
\hline
\end{tabular}




\begin{tabular}{|c|c|c|c|c|c|c|c|c|c|c|c|c|c|}
\hline \multirow{3}{*}{ Gender } & \multirow{3}{*}{ Class } & \multicolumn{6}{|c|}{ Before } & \multicolumn{6}{|c|}{ After } \\
\hline & & \multicolumn{3}{|c|}{ M } & \multicolumn{3}{|c|}{ SD } & \multicolumn{3}{|c|}{ M } & \multicolumn{3}{|c|}{ SD } \\
\hline & & EG & CG & Total & EG & CG & Total & EG & CG & Total & EG & CG & Total \\
\hline \multirow{5}{*}{ Girls } & 2 & 31.75 & 34.13 & 32.94 & 5.01 & 4.88 & 4.93 & 32.63 & 31.50 & 32.06 & 3.42 & 8.77 & 6.46 \\
\hline & 3 & 30.71 & 34.63 & 32.80 & 2.69 & 4.81 & 4.33 & 27.14 & 36.88 & 32.33 & 5.70 & 1.73 & 6.38 \\
\hline & 4 & 35.80 & 31.67 & 33.14 & 2.17 & 2.60 & 3.13 & 37.40 & 31.67 & 33.71 & 0.89 & 2.29 & 3.41 \\
\hline & 5 & 35.69 & 30.80 & 33.55 & 2.66 & 3.99 & 4.14 & 36.25 & 27.20 & 32.14 & 3.25 & 4.71 & 6.23 \\
\hline & Total & 33.69 & 32.66 & 33.15 & 3.96 & 4.26 & 4.12 & 33.53 & 31.54 & 32.49 & 5.24 & 5.98 & 5.69 \\
\hline \multirow{5}{*}{ Total } & 2 & 32.07 & 34.53 & 33.38 & 4.01 & 3.91 & 4.09 & 32.07 & 34.41 & 33.31 & 3.73 & 6.73 & 5.57 \\
\hline & 3 & 30.88 & 33.26 & 32.17 & 4.27 & 5.09 & 4.82 & 27.44 & 33.05 & 30.49 & 5.03 & 5.85 & 6.11 \\
\hline & 4 & 33.11 & 31.93 & 32.58 & 4.80 & 2.46 & 3.91 & 34.61 & 29.87 & 32.45 & 4.74 & 3.94 & 4.95 \\
\hline & 5 & 34.00 & 29.60 & 31.86 & 3.07 & 6.94 & 5.63 & 31.83 & 25.84 & 29.19 & 8.86 & 5.71 & 8.12 \\
\hline & Total & 32.70 & 32.17 & 32.44 & 4.10 & 5.32 & 4.73 & 31.60 & 30.74 & 31.18 & 6.67 & 6.53 & 6.60 \\
\hline
\end{tabular}

Note: EG: experimental group; CG: control group.

In order to investigate the programme's impact on the pupils' attitude towards reading literary texts, a repeated measures ANOVA was conducted (Table 11).

Table 11. Repeated measures ANOVA results: the effect of using comics as a literary-didactic method on pupils' attitude towards reading literary texts.

\begin{tabular}{lcccc}
\hline & $\begin{array}{c}\text { Wilks' } \\
\text { Lambda }\end{array}$ & df & F & p \\
\hline Measurement * inclusion & 1.00 & 1,127 & 0.31 & 0.31 \\
Measurement * inclusion * gender & 0.99 & 1,127 & 0.18 & 0.92 \\
Measurement * inclusion * class & 0.93 & 3,127 & 3.38 & 0.00 \\
Measurement * inclusion * gender * class & 0.92 & 3,127 & 3.54 & 0.01 \\
\hline
\end{tabular}

Note: Measurement: measurement period; inclusion: inclusion in the programme.

The effect of inclusion in the programme on pupils' attitude towards reading literary texts is statistically significant in interaction with measurement period and class, as well as in interaction with measurement period, gender and class (Table 11). However, only one of the paired Bonferroni comparisons was statistically significant. A more detailed analysis of the results presented in Table 10 shows better results for second- and fourth-grade pupils in the experimental group, while for third- and fifth-grade pupils better results were achieved in the 
control group. The study also shows better results for older girls, while for boys no major differences were found with regard to the pupils' age group.

\section{Discussion}

The main purpose of the study was to examine the short-term effect of the systematic use of comics as a literary-didactic method to reduce gender differences in reading literacy and reading motivation at the primary level of education, and to create a basis for a longer lasting experiment. The results of the present study provide an important insight into the use of comics as a literarydidactic method in teaching at the primary level of education. Moreover, they indicate that for a complete insight into the use of comics at the primary level both the pupils' age and gender should be taken into account. These factors should also be considered when drawing up guidelines for further research and for use in the classroom. Our results did not confirm the hypotheses regarding gender and class as potential mediators of the relationship between inclusion in the programme and aspects of reading literacy and reading motivation.

Hypotheses $\mathrm{H}_{1}$ and $\mathrm{H}_{2}$, regarding overcoming gender differences and increasing overall reading literacy, were not confirmed in any of the studied segments of reading literacy and reading motivation, and are therefore rejected entirely. Based on the results of a repeated measures ANOVA referring to pupils' interest in reading literary texts, we also reject hypothesis $\mathrm{H}_{3}$, which assumes a reduction in gender differences, and hypothesis $\mathrm{H}_{4}$, which assumes the overall positive effect of the programme. However, the assumed effect of the use of comics as a literary-didactic method on pupils' reading interest was found in some subgroups, i.e., among fourth-grade boys and fifth-grade pupils of both genders. The hypotheses regarding pupils' attitude towards reading literary texts ( $\mathrm{H}_{5}$ and $\left.\mathrm{H}_{6}\right)$ should also be rejected, as the expected effect of inclusion in the programme was not statistically significant. Nevertheless, the estimated impact of the use of comics on pupils' attitude towards reading literary texts was evident in the case of boys in the fourth grade and in the case of girls in the second, fourth and fifth grades. It should, however, be noted, that boys in the second, third and fifth grades, as well as girls in third grade, showed a greater improvement in the control group.

Pressley, Graham and Harris (2006) defined features of literacy intervention research that, as limitations, also occur in our study. In the present study, randomisation was not possible because the study is quasi-experimental. Quasiexperimental evaluations can find larger intervention effects than true experiments (Cook \& Campbell, 1979; as cited in Pressley, Graham \& Harris, 2006). 
However, based on the results of several studies, Pressley, Graham and Harris (2006) estimate that true experiments and quasi-experiments can still produce roughly the same size effect, with slightly more variable differences for quasiexperiments. The authors also suggest that when the findings are reported only by one experimental or quasi-experimental study, the question of generalising the effects arises: general conclusions can only be drawn by replication of evaluations over different variables (populations, settings, materials and others).

Educational interventions vary in complexity and duration. The majority of interventions are concentrated on smaller, focused interventions with an immediate impact on a specific task. It is rare that evaluations are focused on large interventions with many components that have long-term impacts (Hsieh et al, 2005). The duration of an intervention is not necessarily associated with outcomes, as short, intensive interventions can sometimes offer the most efficient approach (Brooks, 2007; Kerneža \& Kordigel Aberšek, 2014; Vaughn, Gerten \& Chard, 2000). In the area of literacy research, most conclusions are drawn from the results of focused interventions. These focused studies usually provide information for developing more encompassing interventions, as they offer information about shaping more complex treatments (Pressley et al., 2006). Since our study represents one of the first studies that has empirically verified the effect of the use of comics as a literary-didactic method to reduce gender differences in reading literacy and reading motivation at the primary level of education, a short, intensive programme was developed, allowing us to implement the intervention in educational practice for the first time.

Several other limitations should be taken into account when interpreting and generalising the results of our study. Among the teachers who were willing to participate in our research, there were also teachers who expressed concerns about using a comic as a literary work and literary-didactic method. Furthermore, except for the reports of teachers, we did not have any additional insight into the implementation of the programme in practice, which could have enhanced the relevance of the implemented research. The teacher can have a significant impact on the differences in literacy between genders (Lester Taylor, 2004), a fact that is also reflected in the present research. In classes where teachers expressed concerns, the expected effect of the comics was not found. Further studies should therefore examine and monitor teachers' beliefs about using comics as a literary-didactic method and consider them as a factor of the effectiveness of the implemented programme. The impact of teacher's beliefs could be eliminated if the same teacher were to teach in all of the classes. In addition, in some classrooms, boys proved a higher baseline level of the dependent variables than girls, which may have had a significant impact 
on the results of our survey. Due to the small size of the sample, results may be attributed to random factors that were not controlled, thus limiting the ability to generalise our findings.

As one of the first studies to empirically examine the effect of the use of comics in reading literacy and reading motivation, the present research provides an in-depth insight into the use of comics as a literary-didactic method at the primary level of education and can serve as a good basis for further research.

Using comics at the primary level of education has proven to be much more complex than anticipated; it has been shown that the use of comics to reduce gender differences in reading literacy must be explored in four-way methods, and not only in the two-way methods (measurement period ${ }^{\star}$ inclusion in the programme) or three-way methods (measurement period ${ }^{*}$ inclusion in the programme ${ }^{\star}$ gender; measurement period ${ }^{*}$ inclusion in the programme * class) planned in the present research. Accordingly, it is necessary to provide the comics used in the literary-didactic method programme specifically for each class separately, not pairwise for the second and third grades and the fourth and fifth grades, taking the pupils' age into account. Furthermore, the programme should be implemented on a larger sample, which involves agreeing with teachers at least several months prior to the start of the school year. The programme should be carried out by the same teacher in all classes, and this teacher should be qualified to use comics as a literary-didactic method in the classroom, and should have no concerns about doing so. The intervention programme should be extended. It is necessary to add a few sets in which pupils deepen their knowledge about comics as a literary-didactic method, and have an opportunity to use and self-apply the method. The long-term effect of the intervention on pupils' reading comprehension and reading motivation should also be examined.

Both the experience and the results of the research showed that comics as a literary-didactic method used at the primary level of education should be further investigated. In particular, in future studies it is necessary to provide a larger sample of pupils from various backgrounds. In the present study, the designed programme was not proved to be a suitable method for reducing gender differences in reading literacy. In most cases, improvement was identified in the outcome of one gender or the other. This confirms Monica Rosen's (University of Göteborg) argument at an IRC IEA conference, claiming that the best course of action to raise boys' reading literacy is to raise the reading literacy of girls (Rosen, 2007; as cited in Doupona Horvat, 2012), which implies that focusing on a general increase in reading capabilities would also improve the reading results of boys. 


\section{References}

Baker, L. (2003). The role of parents in motivating struggling readers. Reading and Writing Quarterly, 19(1), 87-106.

Below, J. L., Skinner, C. H., Fearrington, J. Y., \& Sorrell, C. A. (2010). Gender differences in early literacy: Analysis of kindergarten through fifth-grade dynamic indicators of basic early literacy skills probes. School Psychology Review, 39(2), 240-257.

Bitz, M. (2004). The comic book project: Forging alternative pathways to literacy. Journal of

Adolescent and Adult Literacy, 47(7), 574-586.

Brooks, G. (2007). What works for pupils with literacy difficulties? The effectiveness of intervention schemes. Retrieved 10.1.16 from: https://www.essex.gov.uk/Business-Partners/Partners/Schools/Oneto-one-tuition/Documents/what_works_for_children_with_literacy_difficulties.pdf. Bucik, N. (2009). Razvijanje otrokove motivacije za branje v domačem okolju [Development of children's motivation for reading at home]. In L. Knaflič (Ed.), Branje za znanje in branje za zabavo: priročnik za spodbujanje družinske pismenosti [Reading for learning and reading for fun: A manual for enhancing family literacy] (p. 17-26). Ljubljana: Andragoški center Slovenije.

Cadima, J., Leal, T., \& Burchinal. M. (2010). The quality of teacher-student interactions: Associations with first graders' academic and behavioural outcomes. Journal of School Psychology, 48(6), 457-482. Conradi, K., Gee Jang, B., \& McKenna, M. C. (2014). Motivational terminology in reading research: a conceptual review. Educational Psychology Review, 26(1), 127-164.

Crane Williams, R. M. (2008). Image, text and story: Comics and graphic novels in the classroom. Art Education, 61(6), 13-19.

Doupona Horvat, M. (2012). Poročilo PIRLS 2011 [PIRLS 2011 report]. Ljubljana: Pedagoški inštitut.

Retrieved 13.12.2013 from http://193.2.222.157/Sifranti/International Project.aspx?id=20.

Edmunds, K. M. \& Bauserman, K. L. (2006). What teachers can learn about reading motivation through conversations with children. Reading Teacher, 59(5), 414-424.

Geske, A. \& Ozola, A. (2008). Factors influencing reading literacy at the primary school level.

Problems of Education in the 21st Century, 6, 71-77.

Graziano, P. A., Reavis, R. D., Keane, S. P., \& Calkins, S. D. (2007). The role of emotion regulation in children's early academic success. Journal of School Psychology, 45(1), 3-19.

Grosman, M. (2006). Razsežnosti branja. Za boljšo bralno pismenost [Dimensions of reading. For better reading literacy]. Ljubljana: Karantanija.

Guthrie, J. T., \& Alao, S. (1997). Designing contexts to increase motivations for reading. Educational Psychologist, 32(2), 95-107.

Guthrie, J. T., Wigfield, A., \& VonSecker, C. (2000). Effects of integrated instruction on motivation and strategy use in reading. Journal of Educational Psychology, 92(2), 331-341.

Hall, L. A., Johnson, A. S., Juzwik, M. M., Wortham, S. E. F., \& Mosley, M. (2010). Teacher identity in the context of literacy teaching: Three explorations of classroom positioning and interaction in secondary schools. Teaching and Teacher Education, 26(2), 234-243. 
Horton, S. V., Lovitt, T. C., \& Bergerud, D. (1990). The effectiveness of graphic organizers for three classifications of secondary students in content area classes. Journal of Learning Disabilities, 23(1), 12-22.

Hsieh, P., Acee, T., Chung, W. H., Hsieh, Y. P., Kim, H., Thomas, D. G. et al. (2005). Is educational intervention research on the decline? Journal of Educational Psychology, 97(4), 523-529.

Kerneža, M. \& Kordigel Aberšek, M. (2014). Strip - metoda, ki fantom omogoča uspešnejšo interpretacijo literarnega besedila [Comics - a method that allows boys a deeper experience of children's literature]. Revija za elementarno izobraževanje, 7(2), 129-145.

Kordigel Aberšek, M. (2008). Didaktika mladinske književnosti [Didactics of juvenile literature]. Ljubljana: Zavod Republike Slovenije za šolstvo.

Kordigel, M. (1999). Komunikacijski model književne vzgoje [A communication model of literary education]. Jezik in slovstvo, 44(5), 151-162.

Kordigel, M., \& Saksida, I. (1999). Jaz pa berem 1. Priročnik za učitelje [I read 1. A handbook for teachers]. Ljubljana: Rokus.

Krakar Vogel, B., Blažić, M. M., Kend, J. J., Seliškar Kenda, M., Cigut, N., \& Meglič, D. (2005). Svet iz besed za učitelje 45 6. Priročnik za učitelje [World of words for teachers 456 . Handbook for teachers]. Ljubljana: Rokus.

Kramarič, M., Ropič, M., \& Urbanič Jelovšek, M. (200o). Na vrtiljaku črk 2: priročnik za učitelje pri pouku slovenščine v 2. razredu devetletne osnovne šole [On the carousel of letters: A teachers' manual for teaching Slovene in the second grade of primary school]. Ljubljana: Rokus.

Lester Taylor, D. (2004). "Not just boring stories": Reconsidering the gender gap for boys. International reading association, 48(4), 290-298.

Linklater, D. L., O’Connor, R. E., \& Palardy, G. J. (2009). Kindergarten literacy assessment of English only and English language learner students: An examination of the predictive validity of three phonemic awareness measures. Journal of School Psychology, 47(6), 369-394.

Lyga, A. A. W. (2006). Graphic novels for (really) young readers: Owly, buzzboy, pinky and stinky. Who are these guys? And why aren't they ever on the shelf? School Library Journal, 52(3), 56-61. Lynn, R., \& Mikk, J. (2009). Sex differences in reading achievement. Trames: A Journal of the Humanities \& Social Sciences, 13(1), 3-13.

Martin, M. O., Mullis, I. V. S., \& Kennedy, A. M. (2007). PIRLS 2006 technical report. Chestnut Hill, MA: Boston College.

Mazzoni, S. A., Gambrell, L. \& Korkeamaki, R. L. (1999). A cross-cultural perspective of early literacy motivation. Reading Psychology, 20(3), 237-253.

McCloud, S. (2010). Kako nastane strip: pripovedne skrivnosti stripa, mange in risanega romana [Making comics]. Ljubljana: Društvo za oživljanje zgodbe 2. koluta: Društvo za širjenje filmske kulture KINO!.

Morrison, T. G., Bryan, G., \& Chilcoat, G. W. (2002). Using student-generated comic books in the classroom. Journal of Adolescent and Adult Literacy, 45(8), 758-767.

Norton, B. (2003). The motivating power of comic books: insight from Archie comic readers. The 
Reading Teacher, $57(2), 140-147$.

Pečjak, S. (1999). Osnove psihologije branja. Spiralni model kot oblika razvijanja bralnih sposobnosti učencev [The basics of reading psychology. A spiral model as a form of developing students' reading skills]. Ljubljana: Znanstveni inštitut Filozofske fakultete.

Pečjak, S., \& Košir, K. (2004). Pupils' reading motivation and teacher's activities for enhancing it. Review of Psychology, 11(1-2), 11-24.

Pečjak, S., Bucik, N., Gradišar, A., \& Peklaj, C. (2006). Bralna motivacija v šoli: merjenje in razvijanje [Reading motivation in school: Measuring and developing]. Ljubljana: Zavod Republike Slovenije za šolstvo.

Pečjak, S., Bucik, N., Peštaj, M., Podlesek, A., \& Pirc, T. (2010). Bralna pismenost ob koncu osnovne šole - ali fantje berejo drugače kot dekleta [Reading literacy at the end of primary schools - Do boys read differently than girls]? Sodobna pedagogika, 61(1), 86-102.

Poznanovič Jezeršek, M., Cestnik, M., Čuden, M., Gomivnik Thuma, V., Honzak, M., Križaj Ortar, M. et al. (2011). Učni načrt. Program osnovna šola. Slovenščina [Primary school curriculum for Slovene language]. Ljubljana: Ministrstvo za šolstvo in šport: Zavod RS za šolstvo.

Pressley, M., Graham, S. \&Harris, K. (2006). The state of educational intervention research as viewed through the lens of literacy intervention. British Journal of Educational Psychology, 76(1), 1-19.

Prvi rezultati PIRLS 2011 [PIRLS first results 2011]. (n. d.). Retrieved 19.12.13 from http://www.pei.si/ UserFilesUpload/file/raziskovalna_dejavnost/PIRLS/IRLS\%202011/Kratka\%2oinformacija\%200\%20 rezultatih\%2oPIRLS\%202011.pdf.

Puklek Levpušček, M., Podlesek, A., \& Šterman Ivančič, K. (2012). Dejavniki bralne pismenosti v raziskavi PISA 2009 [Reading literacy factors in the PISA 2009 survey]. Pedagoški inštitut, Ljubljana. Sadowski, M. (2010). Putting the 'boy crisis' in context: Finding solutions to boys' reading problems may require looking beyond gender. Harvard Education Letter, 26(4), 10-13.

Schwarz, G. (2002). Graphic novels for multiple literacies. Journal of Adolescent \& Adult Literacy, $46(3), 262-265$.

Schwarz, G. (2006). Expanding literacies through graphic novels. The English Journal, 95(6), 58-64. Sheridan, S. M., Knoche, L. L., Kupzyk, K. A., Edwards, C. P., \& Marvin, C. A. (2011). A randomized the effects of parent engagement on early language and literacy: The Getting Ready intervention. Journal of School Psychology, 49(3), 361-383.

Stipek, D. (1996). Motivation and instruction. In D. C. Berliner, R. C. Calfee (Ed.), Handbook of educational psychology (pp. 85-113). New York: Simon \& Schuster.

Sweet, A. P. \& Guthrie, J. T. (1996). How children's motivation relate to literacy development and instruction. The Reading Teacher, 49(8), 660-662.

Štraus, M., Šterman Ivančič, K., \& Štigl, S. (2012). Program mednarodne primerjave dosežkov učencev 2012 - matematični, bralni in naravoslovni dosežki slovenskih učencev: nacionalno poročilo [International students' assessment programme 2012 - Mathematics, reading and science achievements of Slovenian students: National report]. Retrieved 23.09.15 from http://www.pei.si/ UserFilesUpload/file/raziskovalna_dejavnost/PISA/PISA2012/PISA_2012_Povzetek_rezultatov_za_ 
Slovenijo.pdf.

Ulper, H. (2011). The motivational factors for reading in terms of students. Educational Sciences:

Theory and Practice, 11(2), 954-960.

Vaughn, S., Gerten, R. \& Chard, D. J. (200o). The underlying message in learning disabilities intervention research: findings from research synthesis. Exceptional children, 67(1), 99-114.

Versaci, R. (2011). How comic books can change the way our students see literature: one teacher's perspective. The English Journal, 91(2), 61-67.

\section{Biographical note}

MAJA KernežA, graduated in Elementary Education and is currently a Ph.D. student of Education Science in Faculty of Education, University of Maribor, Slovenia. She works with children, parents and teachers. Her recent research focus is concerned with the field of elementary education, reading literacy and the gender gap in education.

KATJA Košır, PhD, works as associate professor at Faculty of Education, University of Maribor. She teaches students of elementary education, primary education, fine arts and music education, and psychology. She also takes part in teacher trainings and carries out psychological counselling for students. Her research and professional work is mainly focused on examining social relations in school context, bullying, teachers' professional development, psychological counselling in school and socioemotional characteristics of gifted pupils. She is an author and co-author of professional and scientific monographs and author of various scientific articles published in national and international scientific publications. 